\title{
Transoral Protrusion of a Peritoneal Catheter Due to Gastric Perforation 10 Years after a Ventriculoperitoneal Shunting: Case Report and Review of the Literature
}

\author{
Ventriküloperitoneal Şant Takılmasindan 10 Yal Sonra Gastrik \\ Perforasyon Yoluyla Peritoneal Kataterin Transoral Protrüzyonu: \\ Bir Olgu Sunumu ve Literatürün Gözden Geçirilmesi
}

Muhammet Bahadır YILMAZ, Emrah EGEMEN, Mehmet TONGE, Memduh KAYMAZ

Gazi University, Faculty of Medicine, Department of Neurosurgery, Ankara, Turkey

Correspondence address: Muhammet Bahadır YILMAZ / E-mail: mbahadiryilmaz@yahoo.com.tr

\begin{abstract}
Various complications following ventriculoperitoneal (VP) shunting have been reported but transoral protrusion of peritoneal catheter is a very rare situation. This case is the first adult with a transoral VP shunt protrusion in available literature. A 47-year-old female with pseudotumor cerebri admitted after the peritoneal catheter protruded from her mouth during retching. Endoscopic examination showed a catheter inside stomach entered through the anterior surface. The patient was treated via VP shunt extraction and remained stable. Extrusion of peritoneal catheter through vagina, anus, scrotal skin or gastrostomy wound is well-known. However transoral protrusion should be considered as a very rare complication of VP shunting, especially in an adult. We present a rare case of transoral protrusion of a peritoneal catheter 10 years after ventriculo-peritoneal shunting procedure and review of the literature through this article.
\end{abstract}

KEYWORDS: Gastric perforation, Peritoneal catheter, Transoral protrusion, Ventriculoperitoneal shunt

öz

Ventriküloperitoneal (VP) şant takılmasından sonra çeşitli komplikasyonlar bildirilmiştir ama peritoneal kateterin transoral protrüzyonu çok nadir bir durumdur. Bu vaka mevcut literatürde transoral VP şant protrüzyonu olan ilk yetişkindir. Psödotümör serebrili 47 yaşında bir kadın ögürrme sırasında peritoneal kateter ağzından çıkınca hastaneye yatırıldı. Endoskopik inceleme midenin ön yüzeyinden girmiş olarak bir kateter gösterdi. Hasta VP şant ekstraksiyonuyla tedavi edildi ve stabil durumda kaldı. Peritoneal kateterin vajen, anüs, skrotum cildi veya gastrostomi yarasından ekstrüzyonu iyi bilinmektedir. Ancak transoral protrüzyon özellikle bir yetişkinde VP şant takılmasının çok nadir bir komplikasyonu olarak düşünülmelidir. Ventriküloperitoneal şant takılması işleminden 10 yıl sonra peritoneal kateterin transoral protrüzyonu şeklinde çok nadir bir vakayı ve literatürün gözden geçirilmesini bu makaleyle sunuyoruz.

ANAHTAR SÖZCÜKLER: Gatrik perforasyon, Peritoneal katater, Transoral protrüzyon, Ventriküloperitoneal şant

\section{INTRODUCTION}

VP shunting procedure is widely performed in the standard surgical management of hydrocephalus. Pseudotumor cerebri (PTC) is a syndrome including chronically elevated intracranial pressure with absence of a hydrocephalus, mass lesion or other related diseases and with normal cerebrospinal fluid (CSF) composition. PTC is frequently a self-limited entity. Most cases benefit from conservative treatment. The primary goal in treatment of symptomatic PTC is the alleviation of symptoms, and the prevention of visual field loss and blindness. When medical therapy fails or progressive visual dysfunction occurs, surgical approaches for PTC should be considered. Basic surgical procedures include optic nerve sheath fenestration and CSF shunting procedures (lumboperitoneal shunting or VP shunting).

Several complications have been described for VP shunting which is performed for hydrocephalus and some essential pseudotumor cerebri cases. The most common complications include shunt migration, infection, malfunction due to occlusion, disconnection, equipment failure and subdural hematoma $(7,29,31)$. Various abdominal complications have been reported ranging from $10 \%$ to $30 \%$ by several authors $(6,17,23)$. However the migration of peritoneal catheter into numerous organs was reported, only 8 cases with transoral protrusions due to gastrointestinal organ perforation were reported in current literature. We present a rare case of 
transoral protrusion of a peritoneal catheter 10 years after ventriculo-peritoneal shunting procedure and review of the literature through this report.

\section{CASE REPORT}

A 47-year-old female had been diagnosed as pseudotumor cerebri who has presented with headache and progressive visual loss 10 years ago. A lumboperitoneal shunting was performed for drug-resistant course in our clinic. During early follow up period, her lumboperitoneal shunt was extracted due to displacement into abdomen and was replaced with a VP shunt. Patient remained stable and asymptomatic for following 10 years. Then she presented with a recurrent headache episode which was set within one month and the peritoneal catheter was self-exposed in her mouth while retching. Systemic and neurological examination showed no abnormalities. Biochemical and microbiological examination of CSF collected by lumbar puncture was within normal ranges. Computed brain tomography (CT) revealed optimally positioned ventricular catheter tip inside narrow right lateral ventricle. But the endoscopic examination showed a catheter inside stomach passing throughout the anterior surface (Figure 1). After the ventricular catheter and dome had excised, a midline supra-umbilical approach was performed. Exploration revealed that peritoneal catheter has been encircled with omentum in anterior portion of stomach which had perforated and entered into corpus of stomach at the anterior surface (Figure 2). Because the catheter was adherent to the stomach, it was excised with surrounding stomach tissue and the defect on stomach was sutured primarily. Culture of extracted shunt material showed no microbial activity (Figure 3). Neither clinical deterioration due
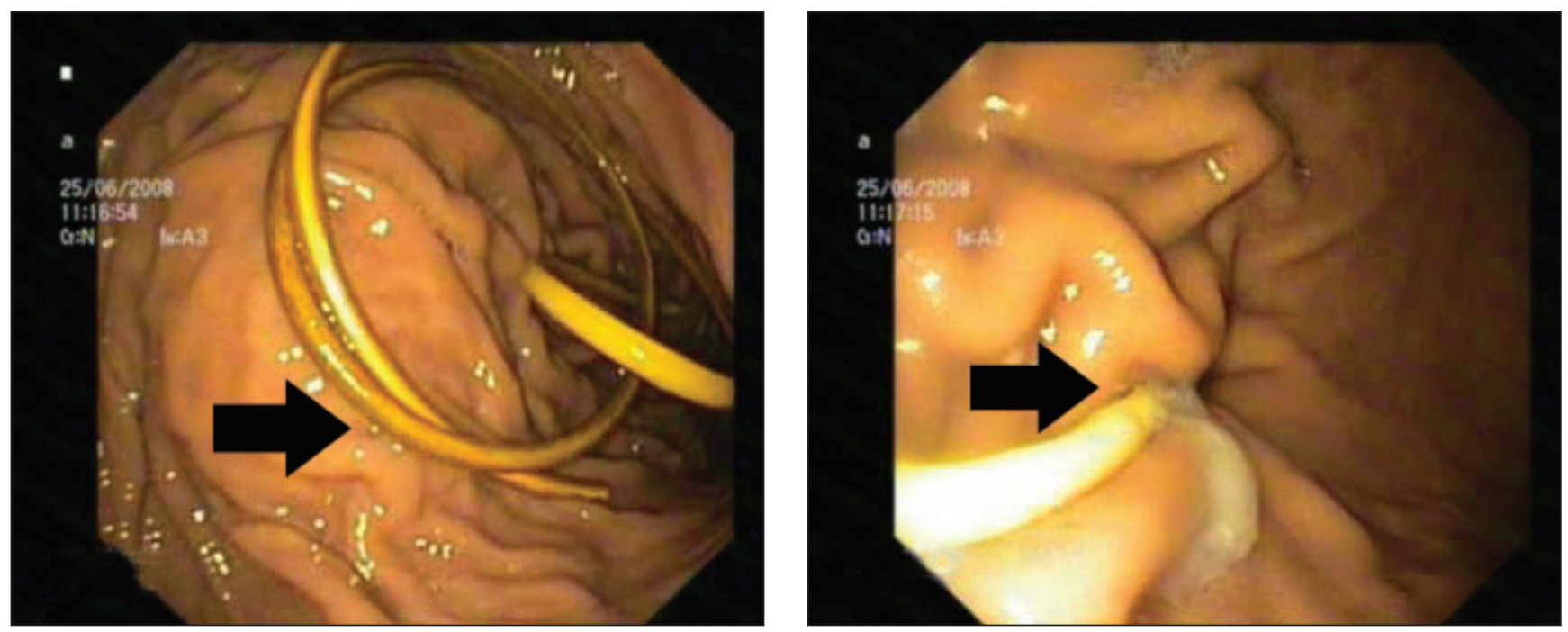

Figure 1: Endoscopic view of peritoneal catheter entering stomach via anterior wall (arrows).

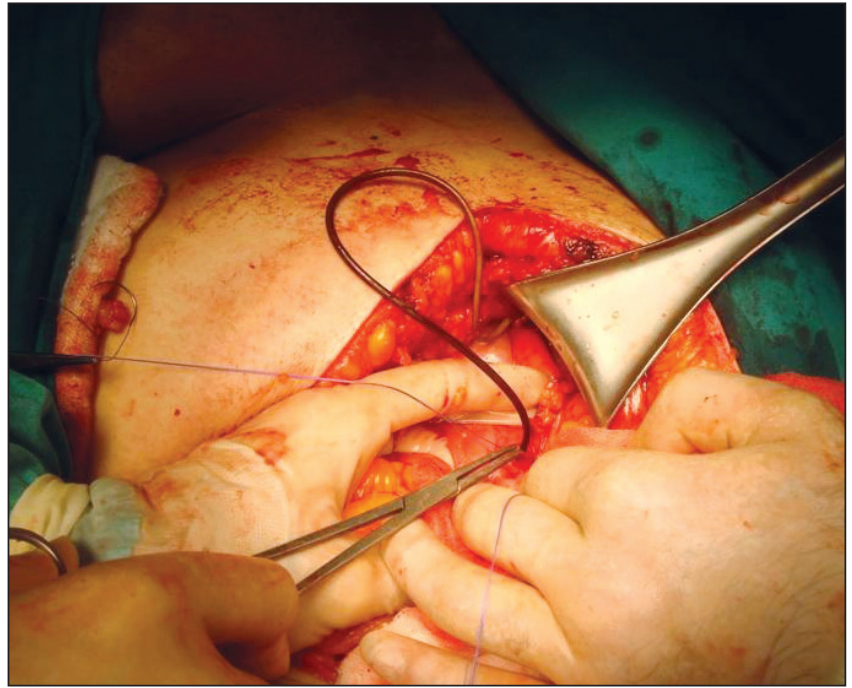

Figure 2: Surgical explorative view of peritoneal catheter perforating stomach.

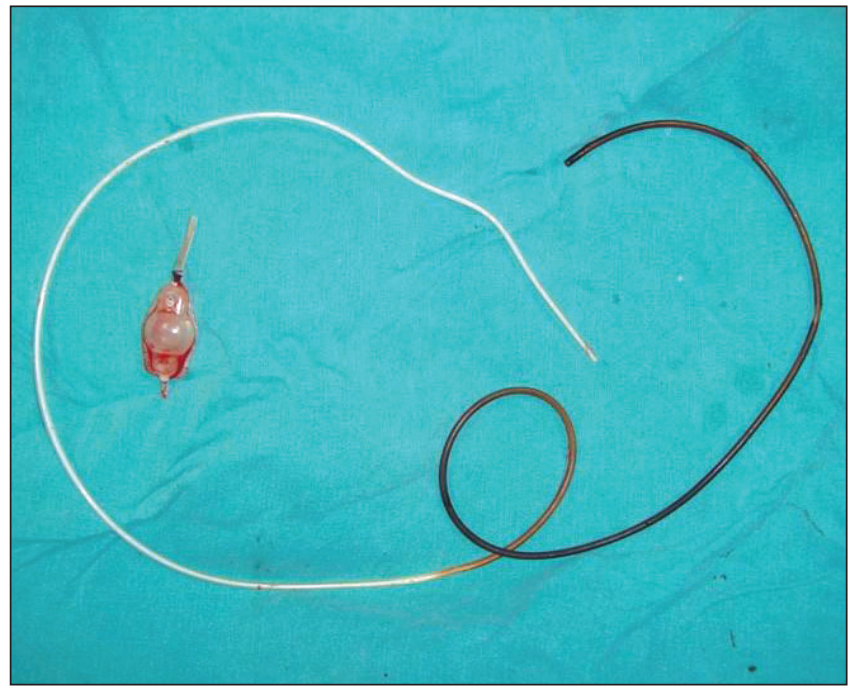

Figure 3: Extracted VP shunt system (dome and peritoneal catheter). 
to recurrent PTC was detected in post-operative follow-ups and nor re-shunting was needed.

\section{DISCUSSION}

High rates of various complications following VP shunting have been reported with an overall incidence of $24 \%$ to $47 \%$ $(8,23)$. Abdominal complications constitute up to $10 \%$ to $30 \%$ as well $(6,17,23)$. Abdominal complications include acute abdomen $(26,31)$, perforation of various abdominal viscera (e.g. colon $(17,21,28)$, stomach $(2,19,21)$, and urinary bladder (21)), peritoneal pseudocyst formation (6), intestinal volvulus (3), inguinal hernia (13) and migration of the distal tip of peritoneal catheter towards different variety of sites $(5,10$, $14,16,22)$. Less frequently, the peritoneal catheter may also extrude throughout vagina (24), anus (1) or mouth $(4,9,11,12$, $15,20,23,29)$, scrotal skin (25), and gastrostomy wound (7).

Wilson and Bertrand were the first authors who reported a case of bowel perforation (BP) caused by a distal shunt catheter (32). Intestinal perforation is a serious complication due to VP shunting which is reported with an incidence of $0.01-0.07 \%$ in the literature. Mortality due to BP is reported approximately $15 \%$ in VP shunted patients $(4,18,27)$.

Various opinions were expressed for preventing gastric and intestinal perforation. Although sharp peritoneal tip or coiled spring type catheters were found to be responsible for perforation, the silicone catheters like in our case might be one of the potential causes of perforation. This situation is mostly seen in young patients. The reported reasons in children are related with weak intestinal wall and stronger intestinal peristalsis compared with elder patients $(19,23)$. Christoph et al. reported that previous operations might be relative with this complication (8). Another viewpoint regarding perforation process is the catheter adhesion to the serosal surface of the bowel theory via foreign body reaction which serves a constant point for repeated pressure. This mechanism results with an ulcer formation gradually on the intestinal wall, eventually leading to perforation (23).
Only eight cases with transoral protrusion were reported in literature. Sridhar et al. have reviewed these cases in literature and built in a table (Table I). A female dominance is apparent (7/1). Our case is an adult unlike previous pediatric transoral protrusion cases. Although none of previous cases have shunt revision history, migrated lumboperitonal shunt was extracted and replaced with a VP shunt 10 years ago in our case. In 3 cases, infectious findings were found on catheter line and microbiological CSF examination revealed microbial origin in 2 cases. The period between VP shunting and occurrence of protrusion was ranging between 3 to 48 months. In our case, the period between shunting and protrusion was as long as 10 years. However most of transoral protrusion cases were caused by gastric perforation, tracheal and jejunal perforations were also reported.

The minority of patients may remain symptom-free despite a gastrointestinal perforation due to shunt migration (18, 21, 27). Although most of patients have complaints of abdominal disturbances before perforation, CT or endoscopy may show no abnormalities in this period. If complaints persist, those evaluations should be repeated. In addition to these points, recurrent meningitis, ventriculitis and indemonstrable fever should be considered as BP. Especially colon perforation accompanies with gram-negative infections. CNS infection which is very important for morbidity and mortality should be excluded if one presents with colon perforation. Empiric antibiotherapy should be administrated following sufficient CSF sample collection. The shunt must be externed. Peritoneal catheter can easily be removed without laparotomy except in cases with peritonitis or peritoneal abscess $(4,30)$. Effective antibiotics should be administrated after detection of responsible microorganism and shunting procedure should be repeated following infection expelling.

\section{CONCLUSION}

Transoral protrusion of peritoneal catheter is a very rare presentation of shunt migration. Our report showed that this

Table I: Summary of Previously Reviewed Cases (Transoral Protrusion of VP shunt)

\begin{tabular}{|c|c|c|c|c|c|c|c|c|}
\hline & $\begin{array}{c}\text { Age } \\
\text { (years) }\end{array}$ & $\begin{array}{l}\text { Sex } \\
\text { (M/F) }\end{array}$ & GI sX' & $\begin{array}{l}\text { Previos shunt } \\
\text { revision }\end{array}$ & $\begin{array}{l}\text { Shunt tract } \\
\text { infection }\end{array}$ & $\begin{array}{l}\text { Time from } \\
\text { VPS (months) }\end{array}$ & $\begin{array}{c}\text { Site of } \\
\text { perforation }\end{array}$ & $\begin{array}{c}\text { CSF } \\
\text { infection }\end{array}$ \\
\hline Griffith et al. & 9.5 & $\mathrm{~F}$ & No & No & No & 3 & Stomach & Yes \\
\hline Park et al. & 5 & $\mathrm{~F}$ & No & No & Yes & 48 & Stomach & No \\
\hline Fermin et al. & 1.5 & $\mathrm{~F}$ & No & No & No & 6 & Trachea & No \\
\hline Odebode & 1.5 & $\mathrm{~F}$ & No & No & Yes & 6 & Jejunum & No \\
\hline Jimenez et al. & 11 & $\mathrm{~F}$ & Yes & No & Yes & $\mathrm{NA}^{2}$ & Stomach & No \\
\hline Sridhar et al. & 0.8 & $\mathrm{~F}$ & No & No & No & 6 & $\begin{array}{l}\text { Stomach } \\
\text { Jejenum }\end{array}$ & No \\
\hline Berhouma et al. & 2 & $M$ & No & No & No & 15 & NA & Yes \\
\hline Danismend et al. & 1.5 & $\mathrm{~F}$ & No & No & No & 10 & Stomach & No \\
\hline Present case & 47 & $\mathrm{~F}$ & No & Yes & No & 120 & Stomach & No \\
\hline
\end{tabular}

${ }^{1}$ GI Sx: previous history of gastrointestinal surgery, ${ }^{2} \mathrm{NA}$ : not available. 
complication may also occur in adult patients and may be delayed as long as a decade following VP shunt procedure. One must keep in mind that the detailed physical examination and radiological evaluation of shunt device should be performed in previously shunted patients who presented with recurrent symptoms.

\section{REFERENCES}

1. Akcora B, Serarslan Y, Sangun O: Bowel perforation and transanal protrusion of a ventriculoperitoneal shunt catheter. Pediatr Neurosurg 42(2):129-131, 2006

2. Alonso - Vanegas M, Alvarez JL, Delgado L, Mendizabal R, Jiménez JL, Sanchez - Cabrera JM: Gastric perforation due to ventriculo-peritoneal shunt. Pediatr Neurosurg 21(3): 192-194, 1994

3. Bal RK, Singh P, Harjai MM: Intestinal volvulus - a rare complication of ventriculoperitoneal shunt. Pediatr Surg Int 15(8):577-578, 1999

4. Berhouma M, Messerer M, Houissa S, Khaldi M: Transoral protrusion of a peritoneal catheter: A rare complication of ventriculoperitoneal shunt. Pediatr Neurosurg 44(2):169-171, 2008

5. Bristow DL, Buntain WL, James HL: Ventriculoperitoneal (VP) shunt migration causing an acute scrotum: A case report of Doppler evaluation. J Pediatr Surg 13(6):538-539, 1978

6. Bryant MS, Bremer AM, Tepas JJ 3rd, Mollitt DL, Nquyen TQ, Talbert JL: Abdominal complications of ventriculoperitoneal shunts. Case reports and review of the literature. Am Surg 54(1):50-55, 1988

7. Chan Y, Datta NN, Chan KY, Rehman SU, Poon CY, Kwok JC: Extrusion of the peritoneal catheter of a VP shunt system through a gastrostomy wound. Surg Neurol 60(1):68-69; discussion 70, 2003

8. Christoph $\mathrm{CL}$, Poole CA, Kochan PS: Operative gastric perforation: A rare complication of ventriculoperitoneal shunt. Pediatr Radiol 25 Suppl 1:S173-174, 1995

9. Danismend N, Kuday C: Unusual complication of ventriculoperitoneal shunt. Neurosurgery 22:798, 1988

10. Doh JW, Bae HG, Lee KS, Yun IG, Byun BJ: Hydrothorax from intrathoracic migration of a ventriculoperitoneal shunt catheter. Surg Neurol 43(4):340-343, 1995

11. Fermin S, Fernández-Guerra RA, Sureda PJ: Extrusion of peritoneal catheter through the mouth. Childs Nerv Syst 12(9):553-555, 1996

12. Griffith JA, DeFeo D: Peroral extrusion of a ventriculoperitoneal shunt catheter. Neurosurgery 21:259-261, 1987

13. Grosfeld JL, Cooney DR: Inguinal hernia after ventriculoperitoneal shunt for hydrocephalus. J Pediatr Surg 9(3):311-315, 1974

14. Hermann EJ, Zimmermann M, Marquardt G:Ventriculoperitoneal shunt migration into the pulmonary artery. Acta Neurochir (Wien) 151(6):647-652, 2009

15. Jiménez Moya A, Penela Vélez De Guevara T, Gracia Remiro R, Romero Escós D, Santana Rodríguez C, Reig Del Moral C, Herrera Martín M: Extrusion of a ventriculoperitoneal shunt catheter through the mouth. An Esp Pediatr 54(6):609-610, 2001
16. Kang JK, Jeun SS, Chung DS, Lee IW, Sung WH: Unusual proximal migration of ventriculoperitoneal shunt into the heart. Childs Nerv Syst 12(3):176-179, 1996

17. Martinez Hernández - Magro P, Barrera Román C, Villanueva Sáenz E, Zavala MJ: Colonic perforation as a complication of ventriculoperitoneal shunt: $A$ case report. Tech Coloproctol 10(4):353-355, 2006

18. Masuoka J, Mineta T, Kohata T, Tabuchi K: Peritoneal shunt tube migration into the stomach: Case report. Neurol Med Chir (Tokyo) 45(10):543-546, 2005

19. Nishijima M, Endoh S, Ohyama H, Higuchi H: Gastric perforation by a ventriculoperitoneal shunt. Neurosurgery 10 (6Pt1):754-756, 1982

20. Odebode TO: Jejunal perforation and peroral extrusion of a peritoneal shunt catheter. Br J Neurosurg 21(2):235-236, 2007

21. Oshio T, Matsumura C, Kirino A, Go M, Bando Y, Manabe $Y$, Nakagawa Y: Recurrent perforations of viscus due to ventriculoperitoneal shunt in a hydrocephalic child. J Pediatr Surg 26(12):1404-1405, 1991

22. Ozveren MF, Kazez A, Cetin H, Ziyal IM: Migration of the abdominal catheter of a ventriculoperitoneal shunt into the scrotum - case report. Neurol Med Chir (Tokyo) 39(4): 313-315, 1999

23. Park CK, Wang KC, Seo JK, Cho BK: Transoral protrusion of a peritoneal catheter: A case report and literature review. Childs Nerv Syst 16(3):184-189, 2000

24. Patel $C D$, Matloub $\mathrm{H}$ : Vaginal perforation as a complication of ventriculoperitoneal shunt: Case report. J Neurosurg 38(6):761-762, 1973

25. Rehm A, Bannister CM, Victoratos G: Scrotal perforation by a ventriculoperitoneal shunt. Br J Neurosurg 11(5):443-444, 1997

26. Reynolds M, Sherman JO, Mclone DG: Ventriculoperitoneal shunt infection masquerading as an acute surgical abdomen. J Pediatr Surg 18(6):951-954, 1983

27. Sathyanarayana S, Wylen EL, Baskaya MK, Nanda A: Spontaneous bowel perforation after ventriculoperitoneal shunt surgery: Case report and a review of 45 cases. Surg Neurol 54(5):388-396, 2000

28. Snow RB, Lavyne MH, Fraser RA: Colonic perforation by ventriculoperitoneal shunts. Surg Neurol 25(2):173-177, 1986

29. Sridhar K, Karmarkar V: Peroral extrusion of ventriculoperitoneal shunt: Case report and review of literature. Neurol India 57(3):334-336, 2009

30. Vinchon M, Baroncini M, Laurent T, Patrick D: Bowel perforation caused by peritoneal shunt catheters: Diagnosis and treatment. Neurosurgery 58(1 Suppl):ONS 76-82, 2006

31. Wani AA, Ramzan A, Wani MA: Protrusion of a peritoneal catheter through the umblicus: An unusual complication of a ventriculoperitoneal shunt. Pediatr Surg Int 18(2-3):171-172, 2002

32. Wilson CB, Bertrand V: Perforation of the bowel complicating peritoneal shunt for hydrocephalus: Report of two cases. Ann Surg 32:601-603, 1966 